EASTERN EUROPEAN JOURNAL OF TRANSNATIONAL RELATIONS

2017 Vol. 1 No. 1

DOI: 10.15290/eejtr.2017.01.01.05

Veranika Radyhina ${ }^{1}$

Maxim Tank Belarusian State Pedagogical University

Iryna Turchanka ${ }^{2}$

Maxim Tank Belarusian State Pedagogical University

\title{
Development of Non-Discrimination Ideas in Education in European Countries and Belarus
}

\begin{abstract}
The article presents a short review of international legislation to ensure equal rights and opportunities for all children, regardless of race, religion, mental or physical development, social status of parents, etc. The most important documents that guarantee the accessibility of education for all children of the Republic of Belarus are disclosed. The idea and objectives of the ELA international project are described.
\end{abstract}

Keywords: nondiscrimination in education; normative and legal support

\section{Introduction}

The accessibility of education is an urgent problem of modern society, which has its own history and its own development path. In this regard, in most democratic

1 Assistant Professor, PhD, Deputy Director of the Institute of Advanced Training and Retraining of Maxim Tank Belarusian State Pedagogical University. Her research interests focus on inclusive education, adult education. Occupational therapy (training and support employment of people with SEN), educational support for children with SEN in inclusive education, building of positive attitudes of teachers of secondary schools and peers to children with SEN. E-mail: radygina@yandex.by.

2 Senior Lecturer, EdM, of the Institute for Advanced Training and Retraining of Maxim Tank Belarusian State Pedagogical University. Her professional interests include: adult education, the development of inclusive approaches to educational practice, information medium of instruction, creation of electronic educational projects, intensive technology training. E-mail: ilukevich@ bspu.by. 
countries of the world, the issues of inclusive education are considered not only as a component of public life, but in a much broader context.

According to Peter Mitler, a professor at the University of Manchester, "Including education is a step towards achieving the ultimate goal of creating an inclusive society that will allow all children and adults, regardless of gender, age, ethnicity, abilities, the presence or absence of developmental disabilities and HIVInfection, to participate in the life of society and contribute to it. In such a society, differences are respected and valued, and with discrimination and prejudice in politics, daily life and institution activity, there is an active struggle" (Kearns, 1995).

The most active desire for humanization of society was manifested after the end of World War II, as a response to atrocities against people not falling under the ideal of "real Aryans": against people with specialties in mental and physical development, against Jews, against racial and social discrimination. The first step towards the recognition of equality was the adoption in 1948 of the Universal Declaration of Human Rights (1948), and just over a decade later in 1959 - the Declaration of the Rights of the Child (1959).

One of the main issues of anti-discrimination policy is the creation of conditions for accessible education, overcoming such inequalities in education as segregation of children according to their abilities, social and economic status of parents, mental, physical, linguistic, cultural and religious differences that can all lead to social conflicts and instability in society. A chance for the entire civil society, one which allows the opportunity to implement in practice the humanistic values of equal rights, freedoms and dignities of each person, is inclusive education (Ovchinnikova, 2011).

\section{International and European basis of the right to education}

In each state inclusive education is focused on its specific category of people, depending on the level of development of the state, priority values in society, economic and political problems. Thus, for some states the problem of overcoming racial discrimination is topical, for others - the attitude in society towards national minorities, for a third - the attitude towards HIV-infected people, etc. Since the mid1960s for many European countries, the problem of including in the life of society and the provision of the right to "full" life to people who have physical or mental disabilities became actual. This is the period of closure of psychiatric hospitals and boarding schools, in the conditions of which "learned helplessness" is formed, there is an atrophy of a person's abilities, a narrowing of the circle of communication, a lack of a full life. However, only the United Kingdom and Italy have completely abandoned the special medical institutions among the European countries.

The issue of ensuring the accessibility of education to various categories of children is reflected in the World Declaration on the Survival, Protection and 
Development of Children (1990). According to the declaration, more than 100 million children did not have a basic school education - two thirds of them being girls. One of the tasks announced to the world community was the provision of basic education and literacy, as well as the opportunity for all children "to identify themselves as individuals and to realize their opportunities in safe and favorable conditions, among family or caregivers, ensuring their well-being. They must be prepared for a natural life in a free society. From an early age, they should be encouraged to participate in the cultural life of their countries".

This declaration also proclaimed commitments among, we can note: the desire to implement programs that will reduce the level of illiteracy and provide all children with the opportunity to receive education regardless of their origin and gender, which will prepare children for work and provide opportunities for lifelong learning; to alleviate the plight of children who live in particularly difficult conditions: victims of apartheid or foreign occupation, orphans and street children, children of migrant workers and victims of natural disasters and disasters caused by human activities, children with disabilities and children undergoing ill-treatment living in adverse social conditions and subjected to exploitation.

The idea of protecting basic social and economic human rights was reflected in the European Social Charter (2000), which is complemented by the content of the European Convention for the Protection of Human Rights and Fundamental Freedoms (1950), which states that everyone has the right to education and all people are equal in rights. A significant event in addressing the issue of nondiscrimination in education was the adoption by the governments of 164 countries, together with global partner organizations, of the Education for All program at the World Education Forum (2000), which is a collective commitment to expand the opportunities for education for different categories of people by 2015 . Six main EFA goals were identified, which reflect the main aspects of basic education: the quality of education, preschool, school and adult education. The Education for all programs is based on respect for human rights, confirms the importance and necessity of learning at any age, and emphasizes the need for specific measures to reach the most vulnerable groups of society.

The progress of this program is reflected in the Global Monitoring Report "Education for All". So, according to UNESCO, for 2008, an additional 72 million children were not school registered. More than half of them were girls, mostly living in areas of the Sahara, Africa or South and West Asia. The main reason for their exclusion is poverty and isolation. Children with disabilities make up one third of all uneducated children. Children belonging to linguistic minorities and nomadic tribes, as well as children infected with HIV/AIDS, are also among those for whom a quality education is not always available (Chiang, 2008, p. 7). However, even today, the problem of primary school enrollment for children living in Third World countries, disabled children, migrant children, etc., remains unresolved. 
One of the main directions in the state policy on overcoming the discrimination in education is the legislative settlement of the issue.

\section{The United Nations' international conventions on the rights of persons with disabilities}

Let us turn to the issue of the legal side of the reforms in education aimed at including disabled people and persons with developmental peculiarities in social relations. In most of the countries that are members of the $\mathrm{UN}$, the legislation has changed in accordance with the legal documents adopted by the UN. If we talk about granting the rights to affordable and high-quality education, to participate in the social life of the state, etc., for persons with special psychophysical development, we can name the following legal documents that determined the reforms in the education of many European countries:

- The Declaration on the Rights of Mentally Retarded Persons (1971), which proclaimed that ,a mentally retarded person has the same rights to the maximum degree of practicability as other people; has the right to education, training, which will enable him to develop his abilities and maximum opportunities; where possible, the mentally retarded person must live with his family and participate in various forms of community life";

- The United Nations Declaration on the Rights of Persons with Disabilities (1975), which became the basis and guide for the protection of the rights of persons with disabilities and proclaimed the right of persons with disabilities to the same civil and political rights as others have; to measures designed to enable them to acquire as much independence as possible;

- The World Program of Action for the Disabled (1982), which aims to promote effective measures to prevent disability, restore work capacity and realize "equality" and "full participation" of people with disabilities in social life and development. This program announced the need to create opportunities for people with developmental features, the opportunities usually available in society and necessary in terms of basic elements of life (family life, education, employment, housing, financial and personal security, access to all types of public services, etc.) in order for a person not to feel inferior. One of the significant points in this program is that it not only calls on governments and the public to provide and protect the rights of disabled people, but also emphasizes that disabled people, having equal rights, also have equal responsibilities - which indicates their full participation in society. Among the measures to overcome discrimination against persons with disabilities, the Program can distinguish the following: when developing national legislation in the field of human rights, national 
committees dealing with disability issues should pay special attention to conditions that may adversely affect the ability of persons with disabilities to enjoy the rights and freedoms guaranteed to their fellow citizens; such specific rights as the right to education, labor, social insurance and protection against inhuman and degrading treatment, etc..

In 1993, UN General Assembly resolution 48/96 adopted the Standard Rules on the Equalization of Opportunities for Persons with Disabilities, the main purpose of which is to ensure that persons with disabilities as members of society have the same rights and duties as others. The Rules set out the main target areas for creating equal opportunities and overcoming discrimination: accessibility, education, employment, culture, recreation and sports, etc., as well as measures to implement them. Thus, the 6th rule refers to the recognition of the principle of equal opportunities in primary, secondary and higher education for persons with disabilities in integrated structures; and the education of disabled persons should be an integral part of the general education system (The resolution 48/96, 1993).

The Salamanca Declaration on Principles, Policies and Practices in the Education of Persons with Special Needs (1994), called on all governments to "adopt the principle of inclusive education in the form of a law or political declaration, that all children enter regular schools, unless there are some serious reasons for compelling otherwise", and to make the inclusion of children with special educational needs a priority of social policy in the state. The Salamanca Declaration proclaimed the idea that every child has the right to education, has unique characteristics, interests, abilities and educational needs, and therefore it is necessary to develop education systems and implement educational programs in such a way as to take into account the wide variety of these features and needs. And those with special educational needs should have access to education in ordinary schools, which should create conditions for them to meet these needs; schools with such an inclusive orientation are the most effective means of combating discriminatory attitudes.

The UN Convention on the Rights of Persons with Disabilities (2006), whose goal is to promote, protect and ensure the full and equal enjoyment by all persons with disabilities of all human rights and fundamental freedoms, as well as in promoting respect for their inherent dignity. The main principles of the Convention are: nondiscrimination, full and effective involvement and inclusion in society, equality of opportunity, equality of men and women, etc.

\section{Development of the relevant regulations in Belarus}

By 2011, the Convention was signed by 147 states of the world and 95 states have since ratified it. In 2013, the Convention was ratified and signed by the Russian 
Federation. In 2016, the Republic of Belarus signed the Law on the Ratification of the Convention on the Rights of Persons with Disabilities (2016).

The adoption of this law is a testament to the desire of the Republic of Belarus in developing and implementing state social policies to be guided by international standards in the field of the rights of persons with disabilities. Recognizing the importance and significance of ensuring the right of persons with disabilities to participate fully in the life of society and protecting their interests, in recent decades the state has been actively working to improve the social protection of disabled people and improve their legal status.

Significant steps in the provision of equal rights to education for persons with disabilities in psychophysical development in the Republic of Belarus were made in the 90 s of the twentieth-century. It was during this period that the first integrated classes (1999) were starting to be created in the republic, providing the opportunity for children with special psychophysical development to have the right to study not in special schools, but in the institution of general secondary education. The development of integrated education and upbringing was accompanied by normative legal documents:

- Decree of the President of the Republic of Belarus No. 15 of July 17, 2008 "On certain issues of general secondary education", providing for the creation of equal opportunities for all citizens to obtain general secondary education that meets the current conditions of social and economic development of the Republic of Belarus;

- Decision of the Ministry of Education of the Republic of Belarus No. 136 of July 25, 2011 "On approval of the Instruction on the procedure for creating special groups, groups of integrated education and training, special classes, classes of integrated teaching and education and organization of the educational process";

- The Code of the Republic of Belarus on Education (2011), defined the principles of state policy in the field of education: guaranteeing the constitutional right of everyone to education and ensuring equal access to education for all; ensuring the accessibility of education, including persons with special psychophysical development in accordance with their state of health and cognitive abilities, at all levels of basic education and in obtaining additional education. It also included the system of special education in the general educational system of the republic.

The development of integrated education and upbringing in the Republic of Belarus was accompanied by scientific and methodological support:

- Methodical recommendations for the organization of integrated teaching and education of students with special characteristics of psychophysical development in general education institutions (2009), which determined the 
organizational forms of integrated education and upbringing; psychological and pedagogical support of children with peculiarities of mental and physical development, who study in conditions of integrated education and upbringing; educational software of integrated training and education; specificity of the organization of the educational process in the context of integrated training and education;

- Methodical recommendations on improving the work on the organization of integrated education and training (2016).

Nowadays, the Republic of Belarus is included in the international movement to provide quality and affordable education for people with special educational needs. So, in 2015 a strategic document ,The Concept of the Development of Inclusive Education of Persons with Peculiarities of Psychophysical Development in the Republic of Belarus" was approved (n.d.), in which it was announced about a broad understanding of inclusive education and its extension to students with special educational needs. However, the most relevant aspect from the point of view of the Republic of Belarus, was the inclusion in a single educational space of persons with special psychophysical development. Inclusive education is considered as a new organization of the educational process. With the purpose of consistent implementation of the Concept, the Minister of Education of the Republic of Belarus has developed a ,plan of measures for implementation in 2016-2020 of the Concept for the Development of Inclusive Education for Persons with Peculiarities of Psychophysical Development in the Republic of Belarus".

Notwithstanding and having given due consideration to all factors involved, we presently see the following as threats to the implementation of inclusive processes in the education system of the Republic of Belarus:

- incompleteness of the regulatory and legal framework governing all aspects of inclusive education (the system of financing of inclusive education, assisting students with special educational needs in the educational space, the filling of classes, the system of assessing the learning achievements of students, the organization of correctional and pedagogical work, etc.);

- unavailability of essential adaptations within the educational environment to implement inclusive practices (ramps, elevators, doorways, no thresholds, specially equipped toilets, etc.);

- functional illiteracy of teachers and parents in matters of educational law;

- unformed inclusive culture of educational institutions (physical, psychological, methodical, didactic, etc.);

- emphasis on the cognitive component of education and diminishing the role of socialization and social development of children as the main task at the level of preschool education and primary school;

- formal inclusion and devaluation of the idea; 
- unformed model of social and professional partnership of teachers, parents, specialists;

- unreadiness of the pedagogical community to implement qualitatively the practices of inclusive education.

\section{Conclusion}

The International Project ERASMUS+ „Development of educational modules for the right for pedagogical training as a contribution to the formation of an education system based on the protection of the rights of participants in the educational process" (ELA), is aimed at improving the functional literacy of teachers in matters of educational law. Within the framework of the project, close cooperation of specialists in the field of jurisprudence and pedagogy is carried out in all 12 universities, as well as involving experts on interdisciplinary problems. ELA began with the idea that increasing equity in education requires cooperation between educators and lawyers. Interdisciplinary cooperation is for lawyers to share legal knowledge, and teachers expressed interest in legal issues and included them in training programs for the training and retraining of managers and educators. Objectives of the project are to:

- develop methods for lawyers to convey legal information to teachers, and methods for preparing teachers and school principals to act in accordance with the law;

- revise plans and programs for the training and retraining of teachers by including 14 modules that contain basic knowledge of legislation and educational rights;

- revise teacher training programs and educational science programs by including 14 modules that contain basic knowledge on legislation and educational rights for students who receive pedagogical education in English, Albanian, Belarusian and Russian;

- develop online testing of 14 modules on legislation and educational rights;

- develop an online toolkit for open learning (for students) and teaching (for educators) on legislation and educational rights;

- disseminate the results of the project through (international) national summer schools, seminars, conferences, forums.

Thus, in conclusion we can say that the non-discrimination of education is guaranteed in the Republic of Belarus by a number of international and national normative legal documents. However, the regulatory framework governing inclusive education needs to be improved. An important direction in the development of the ideas of equal access to education is the improvement of the training and retraining of teachers in the field of educational law. 


\section{DEVELOPMENT OF NON-DISCRIMINATION IDEAS IN EDUCATION...}

\section{REFERENCES}

Chiang, T. (2008). Inclusive Education: Problems of Improving Educational Policy and System.

Decision of the Ministry of Education of the Republic of Belarus No. 136 of July 25, 2011 on approval of the Instruction on the procedure for creating special groups, groups of integrated education and training, special classes, classes of integrated teaching and education and organization of the educational process (2011). Retrieved from http://pravo.newsby.org/belarus/postanov3/ pst702.htm

Decree of the President of the Republic of Belarus No. 15 of July 17, 2008 on certain issues of general secondary education (2008). Retrieved from http://laws.newsby.org/documents/dekretp/ dek00006.htm

Education for All. (2000). World Education Forum. Retrieved from http://docplayer.ru/26703163Dakarskie-ramki-deystviy-obrazovanie-dlya-vseh-vypolnenie-nashih-obshchih-obyazatelstv. html

Kearns, S. (1995). Integration in the Society of People with Special Needs. Presented at the First Moscow International Conference on Down's Syndrome and helping people with intellectual disabilities, Moscow.

Methodical recommendations for the organization of integrated teaching and education of students with special characteristics of psychophysical development in general education institutions. (2009). Retrieved July 9, 2017, from www.asabliva.by

Methodical recommendations on improving the work on the organization of integrated education and training. (2016). Retrieved July 9, 2017, from http://asabliva.by/ru/main.aspx?guid=107053

Ovchinnikova, T. S. (2011). On the issue of studying the experience of inclusive education abroad. Almanah of the Institute of Correctional Pedagogy of the Russian Academy of Education, (14).

Salamanca Declaration on Principles, Policies and Practices in the Education of Persons with Special Needs (1994). Retrieved from http://notabene.ru/down_syndrome/Rus/declarat.html

The Code of the Republic of Belarus on Education (2011). Retrieved from http://pravo.by/ document/?guid=3871\&p0=hk1100243

The Concept of the Development of Inclusive Education of Persons with Peculiarities of Psychophysical Development in the Republic of Belarus. (n.d.). Retrieved July 9, 2017, from http://asabliva.by/ ru/main.aspx?guid=5801

The Declaration of the Rights of the Child (1959). Retrieved from https://www.unicef.org/ malaysia/1959-Declaration-of-the-Rights-of-the-Child.pdf

The Declaration on the Rights of Mentally Retarded Persons (1971). Retrieved from http://www. un.org/ru/documents/decl_conv/declarations/retarded.shtml

The European Convention for the Protection of Human Rights and Fundamental Freedoms (1950). Retrieved from http://www.echr.coe.int/Documents/Convention_ENG.pdf

The European Social Charter (2000). Retrieved from https://www.coe.int/en/web/conventions/ full-list/-/conventions/rms/090000168006b642

The Law on the Ratification of the Convention on the Rights of Persons with Disabilities (2016). Retrieved from http://center.gov.by/18-oktyabrya-2016-g-podpisan-prezidentom-respublikibelarus-zakon-o-ratifikatsii-konventsii-o-pravah-invalidov/ 


\section{EASTERN EUROPEAN JOURNAL OF TRANSNATIONAL RELATIONS}

The resolution 48/96 adopted the Standard Rules on the Equalization of Opportunities for Persons with Disabilities (1993). Retrieved from http://www.un.org/ru/documents/decl_conv/conventions/ disabled_intro.shtml

The United Nations Convention on the Rights of Persons with Disabilities (2006). Retrieved from http://www.un.org/ru/documents/decl_conv/conventions/disability.shtml

The United Nations Declaration on the Rights of Persons with Disabilities (1975). Retrieved from http://www.un.org/ru/documents/decl_conv/declarations/disabled.shtml

The Universal Declaration of Human Rights (1948). Retrieved from http://www.un.org/en/udhrbook/ pdf/udhr_booklet_en_web.pdf

The World Declaration on the Survival, Protection and Development of Children (1990). Retrieved from http://www.un.org/ru/documents/decl_conv/declarations/decl_child90.shtml

The World Program of Action for the Disabled (1982). Retrieved from https://www.un.org/ development/desa/disabilities/resources/world-programme-of-action-concerning-disabledpersons.html 